\title{
Sob o domínio da precariedade: escravidão e os significados da liberdade de trabalho no século XIX
}

\section{Under the domain of precariousness: slavehood and the meanings of work freedon in the $X X^{\text {th }}$ Century}

HenriqueEspada Lima

\section{A utopia da sociedade de mercado}

A sociedadequeseconstruiu no século XIX fundou-se sobre os princípios ideológicos estabelecidos pela economia política no século XVIII: a crença dequeas relações sociais deveriam organizar-separa dar expressão ao impulso "natural" do homem de buscar livree individualmente seus inte resses materiais ${ }^{1}$. 0 modelo desta sociedade é o comércio, o mercado: 0 lugar onde os indivíduos operam segundo uma racionalidade definida pela maximização dos ganhos. 0 impulso da troca eda barganha, que constituiria partecentral da natureza humana, estaria na origem da própria sociedade ea definiria. A economia política - sua fundamentação ideológica - consolidava assim a idéia de uma sociedade governada pela busca individual dos interesses materiais e apontava para a construção de uma ordem social que legitimasse e desse vazão completa a essa "natureza" fundamental do homem. A "sociedade de mercado", quenasce como a utopia construída pela economia política, fundamentava-se na concepção de que a dinâmica da produção edastrocas deveria ser um "sistema econômico controlado, regulado e dirigido apenas por mercados", onde "a ordem na produção edistribuição debenséconfiada a [um] mecanismo auto-regulável"2. 
$\mathrm{N}$ as sociedades préindustriais, os mercados ea troca econômica estavam encapsulados na sociedade, tendo nela um papel freqüentemente marginal com relação à ordenação social emesmo quanto à al ocação de recursos. Com a revolução industrial eseu impacto sobreo capitalismo mercantil, abriu-se a possibilidade de se pensar a organização econômica de modo desarticulado da organização social, desencampsulando a economia da sociedadee, no limite, invertendo o processo, subordinando a própria socie dadeà lógica dos mercados e, desse modo, à economia ${ }^{3}$.

Esses são os termos que definem, de um modo bastante geral, o modelo de organização socioeconômica que guiou grande parte das decisões políticas das elites ligadas à produção industrial eà haute financea partir do final do século XVIII, especialmentena Europa 0 cidental enaAmérica. As origensintelectuais dessemodelo, da economia política e do liberalismo (político eeconômico), são bem anteriores etêm um lugar fundamental na históriaintelectual epolítica da época modernae contemporânea, mas não serão objeto deste trabalho ${ }^{4}$. Por outro lado, val e constatar que a implantação de uma sociedade de mercado que correspondesse inteiramentea esse modelo ideal-típico esboçado antes, nunca ocorreu completamente em lugar al gum. As razões disso tal vez estejam, como sugere Polanyi, no fato de que uma utopia com essas características - por razões que voltarei a tratar a seguir não poderia ser implantada inteiramentesem destruir o próprio tecido social da sociedadeem que isso fosse tentado ${ }^{5}$. N ão obstanteesta constatação, é inegável queestemodelo se constituiu em um elemento central na compreensão einterpretação da real idade social e econômica neste período $0^{6}$.

No campo de disputas pela condução da sociedade a partir do início do século XIX, o papel preponderante dos modelos da economia clássicaé incontestável. É também certo que a tentativa de implantação real deste modelo foi sentida mais fortemente pelos trabal hadores do que por qualquer outro grupo social.

\section{Liberdade de contrato e precariedade}

$\mathrm{N}$ a Inglaterra, berço da indústria e da economia política, o primeiro impacto das idéias liberais ocorreu sobre o acesso à terra e sobre a dinâmica dos preços dos produtosagrícolas. A influência das medidas liberais sobre as 
formas de organização da sociedade e da economia das classes subalternas foi intensa e discutida por uma historiografia atenta ao sentido político das lutas dos trabal hadores no período7. Sua reverberação na organização do trabal ho foi igualmente sentida e está presente nas preocupações dos próprios contemporâneos.

Antes da revolução industrial, o trabal ho regulado e o trabal ho forçado eram as duas modalidades principais de organização do trabalho ${ }^{8}$. As regulamentações das profissões no Antigo R egime, especialmentenas cidades, impediam a "existência de um mercado em que as mercadorias circula[ssem] livremente: nem concorrência, nem liberdade de aumentar a produção. M as também imped[iam] a existência de um mercado detrabaIho: nem liberdadedecontratação, nem liberdade decirculação detrabalhadores" ${ }^{\prime}$. Essa organização do trabal ho engessava as relações laborais, ea rigidez desuas regras impedia o desenvolvimento deum processo deacumulação capitalista, dificultando o fluxo de matéria-prima e mão-de-obra para a indústria, bloqueando a expansão da produção $0^{10}$.

$\mathrm{N}$ ão por acaso, a desarticulação desse sistema de trabal ho fundamentado na regulação, coerção etutela, foi a tarefa fundamental de reformulação das relações de produção imposta pela ideologia do mercado. 0 imperativo da "liberdade" como parâmetro fundamental que deveria guiar a reorganização do mundo do trabal ho se impôs de modo contundente nas discussões sobre as relações entre a sociedade e o trabal ho a partir do final do século XVIII. Robert C astel sugere que a instituição do "livre acesso ao trabalho" tem, no campo propriamentejurídico, um impacto revolucionário paralelo ao da própria revolução industrial (da qual considera a "contrapartida"): "N a verdade, reveste-se de uma importância fundamental com relação a tudo que a precede. Q uebra as formas seculares de organização dos ofícios e faz do trabalho forçado uma sobrevivência bárbara"11. Assim, a constituição, nesses termos, de um mercado de trabal ho livre impunha-se como uma tarefa central. A forma e os atributos destemercado, entretanto, não eram óbvios.

Um dos aspectos centrais desse processo foi a promoção de uma modalidade de trabalho que havia sido não apenas marginal e sufocada pelo regime detutelas, mas que era considerada então propriamente degradante: a condição do assalariado. Em outras palavras, essa "revolução" dava espaço 
e colocava em seu centro um tipo de relação de trabal ho que se baseava na idéia de que o trabalhador deveria sobreviver unicamente da venda ou aluguel das suas forças.

0 "livre acesso ao trabalho" tendo se tornado, como afirma C astel, "unanimidade" entre os "partidários do Iluminismo"12, trouxe resultados não previstos pelos seus próprios formuladores. A "libertação" da condição operária teve suas conseqüências: Ao lado de um aumento da abundânciae da riqueza sem precedentes, o que se viu também com mais força a partir do final do século XVIII foi a ascensão, nos mesmos países que lideravam a produção industrial e abraçavam o livre comércio, de um tipo de pobreza que era igual eterrivelmentenovo.

0 fenômeno do "pauperismo" - que chamou a atenção, no início do século XIX, depensadores ereformadores tão distintos quanto o utilitarista Jeremy Bentham, o liberal Alexis de Tocqueville e o socialista Robert 0 wen $^{13}$ - acabou por revelar essa face aparentemente incompreensível da sociedade de mercado. A indigência demassa queacompanhava a prosperidade diferia enormemente da miséria e da mendicidade no Antigo Regime (onde aparecia como uma situação excepcional, fora do "regime comum" da pobreza). 0 "elemento novo", que já começa a aparecer bem antes do século XIX, mas que se expõe radicalmente então, é precisamente uma "vulnerabilidade de massa"14, isto é, uma precariedade das condições da existência queéestrutural nessa sociedade, onde as relações de trabal ho passam a ser marcadas não apenas pel os baixos salários, mas também pela "instabilidade do emprego, a busca de ocupações provisórias, a intermitência do tempo de trabalho" e a própria ausência de emprego ${ }^{15}$. $\mathrm{N}$ ão se tratava de situações excepcionais ou marginais, mas de uma condição que estava no horizonte de todo trabal hador em uma sociedade definida por um princípio demercado que exigia, para funcionar, a própria precariedadeda relação detrabalho. 0 vagabundo eo indigenteno mercado de trabalho "livre" não são figuras periféricas, mas revelam o cerne da nova condição do trabal hador: trata-se de "uma indigência que não é devida à ausência de trabal ho, mas, sim, à nova organização do trabalho, isto é, ao trabal ho 'liberado'"'16.

$M$ as, quais el ementos dessa nova organização do trabalho irão determinar a condição deprecariedade que marca o início do século XIX edefine os contornos da "questão social" no período? 
A característica distintiva da organização do trabal ho sob o regimedo mercado está, como disse antes, na sua nova organização jurídica. Seu princípio central pode ser resumido na idéia de "contrato". 0 "livre contrato" passa a ser o modelo fundamental dos arranjos de trabalho em uma sociedade definida pelas regras da "livre" concorrência. A ordem contratual supunha que o trabal ho era uma mercadoria colocada à venda em "um mercado queobedeceà lei da oferta eda procura". A relação entre o trabal hador eseu empregador não é mais definida pela dependência, a tutela ou a coerção, mas torna-se "uma simples 'convenção', isto é, um contrato de dois parceiros que se entendem sobre o salário"17.

Assim, como apontou Polanyi, a definição do "trabalho livre", nesse contexto, derivava de uma "visão de mercado da sociedade, que igualava a economia a relações contratuais, e as relações contratuais com a liberda$\mathrm{de}^{\prime 18}$. 0 sentido imediato da nova ordem contratual era pensar a sociedade fragmentada em indivíduos, queeram definidos como "produtores" e "consumidores" operando no mercado. Assim, para que se implantasse de fato uma ordenação contratual do trabalho "livre", o que se pedia aos trabal hadoreséque compreendessem que seus "verdadeiros interesses" não significavam a garantia "contra a miséria através de um salário seguro, mas, sim, em esposar a ideologia liberal que os coloca em situação de concorrência, remunera as 'faculdades' eos 'tal entos', penal iza os medíocres e os fracos' 19 .

A "liberdade" contida nesta nova situação não era, obviamente, desprovida de ambigüidades. Seu significado poderia variar - e variava - de acordo com a posição que cada "indivíduo" ocupava em uma relação contratual que, a despeito da sua descrição ideal, era absolutamente desigual. A reivindicação do livre acesso ao trabalho, nessestermos, não foi uma reivindicação dos próprios trabalhadores (quecertamentenão compreendiam a "liberdade" nos mesmos termos dos economistas), mas dos reformadores pol íticos que parecem ter imposto o "livre contrato detrabaIho" numa "relação de dominação política"20.

A questão central aqui éque a implantação de um mercado de trabaIho revelava exatamente o caráter destruidor da utopia da sociedade de mercado queo sustentava. 0 equívoco principal quejustificava essa utopia era a consideração daterra, do trabalho edo dinheiro como mercadorias. Como demonstrou Polanyi, a definição empírica de mercadoria não contempla de 
nenhum modo esses elementos da indústria:21 a "força de trabalho" definida em termos abstratossignificava, concretamente, a vida humana dos trabaIhadores, que "não pode ser impelida, usada indiscriminadamente, ou até mesmo não utilizada, sem afetar o indivíduo humano que acontece ser 0 portador dessa mercadoria peculiar."22

0 que estava em jogo, portanto, era a própria viabilidade da coesão social e da sociedadeem última instância. Como afirma C astel, a implantação da sociedade de mercado associava ao mesmo tempo o "voluntarismo político" - que colocava o problema de assistência aos pobres como uma questão desvinculada da organização da economia- e o laissez-fairena organização do trabal ho. Ao fazer isso, acabava por liberar "antagonismos sociais" que os promotores dessa utopia não eram capazes de prever e muito menos controlar ${ }^{23}$.

0 que a liberalização selvagem do trabal ho no início do século XIX revela é precisamenteisso. 0 modelo do mercado desregulado previa quea "livre" dinâmica das contratações faria emergir natural mente uma ordenação racional do trabalho. 0 que a real idade das novas relações de trabal ho revel ava era completamente diferente:

Eliminando-se as proteções tradicionais, corre-se o risco de fazer aflorar não a racionalidade das leis naturais mas, sim, o poder biológico dos instintos: os carentes serão então impelidos pela necessidade natural, isto é, pela fome. Sobre o pano de fundo da reciprocidade jurídica do contrato de trabalho, perfila-se, assim, a alteridade fundamental das posições sociais dos contratantes, e o espaço pacificado das relações comerciais transmuta-se num campo de batalha para toda a vida quando se reintroduz a dimensão temporal no contrato de trabalho. 0 empregador pode esperar, pode contratar 'livremente', pois não está sob o domínio da necessidade. 0 trabalhador é determinado biologicamente a vender sua força de trabalho, pois está na urgência, tem necessidade imediata de seu salário para sobreviver. ${ }^{24}$

Superado o mundo do trabal ho tutelado eforçado, o que se descobre équea "condição operária se torna frágil ao mesmo tempo em que seliberta". Essa fragilidade consistena descoberta de que "a liberdade sem proteção podelevar à pior servidão: a da necessidade"25. A "liberdade" do assalariado de carne e osso dispunha apenas dos seus "atributos negativos" . 0 confronto entre "liberdades" desiguais revel ava assim a "face sombria" da liberdade, 
isto é, "a individual idade negativa de todos aqueles que se encontram sem vínculose sem suportes, privados de qualquer proteção equalquer reconhecimento"26

A nova ordem do contrato não poderia se estabelecer como fundamento de uma ordem estável para a sociedade, já que o seu funcionamento efetivo não apenas produzia a instabilidade constante- na medida em que lançava os trabal hadoresnainsegurança com relação ao seu próprio futuro mas exigia essa instabilidade para viabilizar-se. Assim, no momento mesmo em que o trabal ho se torna o elemento integrativo por excelência da nova ordem social, eleéprivado das condições efetivas para exercer esse papel. A nova condição de precariedade de massa que daí resulta promovea questão que está no cerne das lutas políticas dos trabalhadores no século XIX ${ }^{27}$ : a luta contra a precariedade da condição salarial e a constante ameaça de desfiliação socia| ${ }^{28}$ que se coloca em seus limites.

\section{0 modelo do "mercado de trabalho livre"}

Pelas suas próprias características intrínsecas, a implantação de um mercado de trabalho "livre" não se deu de modo homogêneo e inconteste em lugar al gum. Ao contrário, em torno dos significados dessa "liberdade" seestabeleceu um campo de lutas de enorme complexidade extensão. Sua realidade empírica traduziu-se em configurações quevariaram desdea situação ideal-típica do trabal hador independenteassalariado atéuma miríade de arranjos detrabal ho querecombinavam graus diversos de "liberdade" ecompensação financeira pelo trabalho, com elementos de coerção (física e pecuniária), tutela, trabal ho compulsório e contratado, eainda formas análogas à escravidão, como a servidão por dívida. Como resultado dos conflitos em torno do seu significado e al cance, o "trabalho livre" construiu-se como uma realidade ambígua e, no limite, uma "ficção instável", mesmo em países como a Grã-Bretanha e os Estados U nidos da Améric ${ }^{29}{ }^{29}$ o sécuIo XIX eao menos nas primeiras décadas do seguinte.

A despeito disso, a imagem da sociedade contemporânea como o resultado da ascen são constante de uma organização social baseada na "racionalidade" ena "liberdade" - enfrentando apenas resistências maisou menos localizadasquesão, em última instância, fadadas ao fracasso - continua a ter 
enorme influência sobre os modelos que pretendem explicar o sentido das transformações sociaise institucionais que marcaram osúltimos dois séculos.

0 exemplo mais claro disso está na insistência com que essa imagem contamina as discussões sobre as transformações sofridas nas sociedades escravistas, sobretudo nas Américas, durante o século XIX. N o contexto dessas sociedades, a "liberdade de trabal ho" se apresenta como a oposição radical ao trabalho escravo. U ma contraposição que parece auto-evidenteespecialmente se pensada a partir dos termos estabel ecidos pela economia clássica - mas que é, na verdade, tão carregada de ambigüidade quanto 0 modelo de sociedade em que se inspira.

Robert Steinfeld afirma quea convicção de que existe um corte seco e limpo que separa o trabal ho escravo e o trabal ho livre é fundada em uma "sabedoria convencional" quetraduz em termos de um modelo aquilo que é de fato uma narrativa evolucionista sobre a história do trabalho $0^{30}$. Uma narrativa que traduz essa história como o processo que, lentamente e em paralel o à história política das sociedades da Europa 0 cidental, faz nascer 0 "moderno" mercado detrabal ho livreassalariado, contrapartida institucional ejurídica do "moderno" estado burguês.

Essa "narrativa tradicional do trabal ho livre" vem sendo, entretanto, sistematicamente desafiada por estudos que tentam entender o seu verdadeiro funcionamento em situaçõeshistóricas específicas. Antes demaisnada, em termos ideais, o mundo do trabalho livre supõe: liberdade de escolha, ausência decoerção para o trabalho, capacidadedemobilidadedostrabalhadores, impessoalidadena relação patrão/empregado, mastambém oferta de oportunidades de trabal ho e possibilidades de acesso a elas por parte dos trabalhadores. Além disso, elesupõe quea ausência de coerção para o trabaIho seja um valor partilhado também pelos empregadores. Bem, o que os estudos sobre o funcionamento do mercado de trabalho do século XIX, como o do próprio Steinfeld, demonstram, é que essa configuração do mercado de trabalho élargamenteirreal. Como modelo, na medida em que retifica as categorias com que se lida com as várias modalidades de arranjos de trabalho, acaba por embaçar a vista para o real funcionamento desse "mercado"31.

Como sugere Tom Brass, a questão aqui é que a "oposição teórica" entre a liberdade e a não-liberdade não é natural, mas construída ${ }^{32}$. D o 
mesmo modo, tanto o trabalho assalariado quanto o trabalho não-livrenão possuíam um conteúdo fixo e demarcado. C aracterísticas definidoras do trabalho livre, como a compensação financeira pelo trabalho, em forma de salário ou outro, não eram incomuns na relação escravista. Formas de barganha coletiva - como o "cruzar os braços" - que costumam ser pensadas apenas com relação aos trabal hadores livres da indústria, estiveram igualmentepresentes em alguma medida entreas estratégias dos escravos em suas negociações com seus senhores eadministradore ${ }^{33}$. Por outro lado, formas de trabal ho forçado (que incluía diversas formas de contrato, indentured labor, servidão por dívida, patronage eoutros), assim como a coerção física para o trabal ho, faziam parte do cotidiano dos trabal hadores livres durante e depois do período escravista. Para o N orte dos Estados Unidos antes da Guerra C ivil, por exemplo, a maior parte do trabal ho manual realizado por brancos livres dificilmente poderia ser considerada, pelos critérios evalores de hoje, como "trabal ho livre": faltava-Ihe, entre outras coisas, o direito à negociação coletiva, o direito à sindicalização, ou qual quer garantia contra a invalide ${ }^{34}$. Enfim, modalidades de trabal ho "não livre" foram usadas em várias partes do globo, tanto em lugares que não conheceram a escravidão nos moldes americanos (como a Índia sob domínio britânico), quanto na África, onde o próprio combate à escravidão era usado como justificativa para a intervenção colonial35.

A verdade éque, como já foi apontado, "definir escravidão e liberdade" provocou eprovoca "angústias políticas e conceituais" 36 . 0 conceito de trabalho livreéprova disso. Elemostrou ser um eixo fundamental de debate e disputa porque colocava em jogo não apenas questões econômicas sobre a organização e distribuição da força de trabalho, mas especialmente porque foi capaz de mobilizar, do mesmo modo, temas como o do direito ao trabalho, a dignidade do trabalho e o acesso aos direitos políticos quea "liberdade" implicava ou poderia implicar. Em torno do seu significado poderia construir-se, de resto, tanto 0 argumento político dos trabalhadores por acesso à cidadania, quanto o argumento dos empregadores contra a associação sindical ${ }^{37}$.

De todo modo, o que essa discussão mostra é que a narrativa evolucionista do desenvolvimento do trabalho livreem uma moderna economia demercado desenhaum quadro excessivamentesimplificador sobre 
o problema da relação entre "liberdade" etrabalho. 0 quevalea pena apontar, portanto, é que o caráter irrealista desse enredo teleológico constrói uma interpretação da sociedade capitalista contemporânea a partir da imagem que ela produziu para si mesma. Ao fazer isso, ela acaba por reforçar como chamou Polanyi havia décadas - nossa "ultrapassada mentalidade de mercado", que enxerga o sistema de mercado e as suas instituições como 0 ponto culminante ea aplicação efetiva de conceitos como "liberdade, justiça, igualdade, racionalidadee ordem legal" 38 .

\section{Os sentidos da "transição"}

$\mathrm{N}$ ão há dúvida de que a historiografia sobre a escravidão nas últimas décadas avançou imensamente na direção de compreender de um modo mais denso o funcionamento da sociedade escravista no Brasil enas Américas. D imensões fundamentais da experiência dos escravos foram exploradas com cuidado em diversos trabal hos quelançaram luz sobreas ações autônomas dos escravos no sentido de minar a legitimidade da escravidão, bem como suas estratégias para construir - dentro efora das relações escravistasum universo viável de relações sociais. Assim, as formas de resistência e negociação dosescravos, suas redes desociabilidade, o lugar ea permanência de suas relações familiares, sua cultura, e as formas de luta sob o cativeiro foram amplamente discutidos ${ }^{39}$.

Aspectos fundamentais do sistema escravista permaneceram, entretanto, menos explorados, especialmente no que concerne aos sentidos e aos significados da liberdade. A pergunta sobre o que existe para além da escravidão muitas vezes comportou respostas que, ao mesmo tempo que analisavam com detal he o trabalho escravo em suas dimensões econômicas, sociaise políticas, com muita freqüência acabaram por tratar a liberdade como um conceito indiferenciado e que raramente era colocado em exame. ${ }^{40}$

M esmo aqueles trabal hos que enfrentaram diretamente o problema do "significado da liberdade", indagaram antes de tudo sobre suas dimensões culturais e políticas em sentido amplo - iluminando, por exemplo, questões referentes à cidadania, raça e etnia ${ }^{41}$. Assim, a questão dossignificados que "trabal ho livre" poderia ter nos vários contextos do pós-emancipação ainda merece al guma atenção. Ao enfrentar esse problema, denunci- 
ando diretamente, por exemplo, o etnocentrismo dos conceitos da economia políticano quese refereàs concepções dos escravos, vários estudosacabaram deixando sem combate essas mesmas concepções quando tratavam das relações detrabal ho que os ex-escravos encontravam fora da escravidão.

0 fato éque a questão geral que atravessa a abolição da escravidão nas Américas é que ela significou antes detudo a extinção do direito de propriedadeem sereshumanos. É claro quechama-seisso, um tanto emotivamente, "liberdade", antes de tudo por motivos políticos, mas também pela influência direta dos parâmetros da economia política. $M$ as, nas sociedades escravistas do século XIX, "liberdade" e "escravidão" são termos sobretudo jurídicosquesereferem à propriedadeenão são automaticamentetraduzíveis como "trabalho livre" e "trabalho escravo". Transferir os sentidos que eles carregam desde um espectro do campo jurídico para outro não pode ser feito sem um exame cuidadoso da pertinência dessemovimento. 0 perigo da sobreposição das duas ordens de sentido - valea penainsistir - acaba por conduzir a interpretações viciadas que se traduzem na leitura das sociedades escravistas (e da sua transformação e dissolução) em termos insi stentemente evolucionistas. A insistência no sentido da "transição" do trabal ho escravo para o trabalho livre, tal como foi sistematicamente colocada por uma longa tradição de estudos sobre o sentido socioeconômico da escravidão e da abolição no Brasil, é um exemplo claro disso ${ }^{42}$.

Sílvia Lara argumentou há al guns anos que a tradição historiográfica que discutia a "transição" havia sido responsável por justificar, por exemplo, a invisibilidade da presença dos ex-escravos na história dos movimentos dos trabal hadores no Brasil pós-emancipação ${ }^{43}$. A lógica evolucionista havia decidido quea marca das relações de trabal ho escravistas havia tornado um grupo expressivo de indivíduos incompatíveis com as regras da nova sociedade "moderna" baseada no trabalho livre. A "substituição" de uma forma detrabal ho pela outra implicaria, no limite, a própria substituição física dos antigos escravos pelos imigrantes europeus supostamente educados para se comportarem como indivíduos "modernos" compatíveis com as regras do mercado. Essa "substituição", entretanto, deixaria um resto, uma sobra perfeitamente dispensável no que diz respeito à explicação da organização do trabalho, assim como aluta dos trabal hadores, no pós-escravidão. Esteresto seria o próprio mundo dos ex-escravos. 
No campo da história da escravidão, como afirmei, muito já se fez para escapar a lógica evolucionista e interrogar a experiência dos escravos através dos seus próprios termos. Por outro lado, no caso das experiências dos livres elibertos pobres, muitas vezes, enfatiza-se antes detudo a análise dasformas de dominação ea manuten ção dasformas arcaicas de dependência, tendo como contraponto uma imagem idealizada de uma sociedade fundada em princípios racionais.

Assim, em algumas das reflexões de caráter sociológico sobre a experiência dos livres pobres edependentes no Brasil escravista ${ }^{44}$, constrói-seàs vezes uma imagem da sociedadebrasileira ondese reconheceracionalidadee cálculo para apenas um dos pólos da relação senhorial. São análises que opõem uma classe deproprietários queoperam dentro da lógica "moderna" da maximização a uma classe de desprovidos e dependentes que agem a partir de uma lógica definida como "tradicional" e desprovida de racionalidade. 0 ra, me parece que essa oposição idealiza, por um lado, o sentido das ações dos "novos" sujeitos, enfatizando seu individual ismo, sua compreen são e clareza sobre seus próprios "interesses" 45 , seu acesso ilimitado à informação e recursos, univocidade das ações e coerência de suas estratégias, etc; e, por outro lado, subestima largamente qualquer componente "racional" das ações dos trabal hadores livres dependentes, supostamente imbuídos de um comportamento (social e econômico) reativo e visceral, incapazes de inovação e aprisionados a redes de dominação que são, em última instância, "sobrevivências" da escravidão.

0 que liga o tema da "transição" à discussão sociológica que analisa a sociedade brasileira a partir das suas "faltas" é precisamente a existência de um contraponto regulador que orienta os critérios de análise: a sociedade como deveria ser, isto é, a concepção ideal izada de um modelo ordenado onde as relações econômicas e sociais são marcadas pelo paradigma de uma sociedade definida pela racionalidadee a impessoal idade ${ }^{46}$.

\section{Sob o regime do contrato: arranjos de trabalho para além da escravidão}

N a América escravista, a idéia de "contrato" era central para os distintos projetos - e processos - de emancipação ao longo de todo o século 
$X \mid X^{47}$. N o Brasil, o lento egradual processo de emancipação foi construído em paral elo com a inserção paulatina de uma legislação quetinha, antes de tudo, 0 objetivo de disciplinar e ordenar o mercado de trabalho no país, contemplando tanto os contingentes de trabal hadores imigrantes quanto os egressos da escravidão. À introdução de regras legais que regessem os contratos entre patrões e empregados se deu particular atenção $0^{48}$. A ênfasena elaboração das leis, nas concepções dos legisladores e nas lutas políticas das elites em torno dos termos dessa nova organização do trabal ho em relação a seus interesses econômicos ocupou a maior partedas análises desenvolvidas sobre essetema. 0 efetivo funcionamento ea análise detal hada dosarranjos de trabalho que ocorreram sob a nova lógica do contrato e do trabalho "livre" foram, entretanto, bem menos estudados.

A legislação portuguesa, que valia no Brasil mesmo após a Independência, tratava de modo restrito o problema das relações de trabal ho. As O rdenações Filipinas, quese referiam ao quechamaríamos de "direito civil" (e que tiveram vigência no Brasil atéo início do século XX), tratavam das relações entre senhores e criados no seu livro IV ${ }^{49}$, prescrevendo sobre as formas e valores de pagamento de soldadas e serviços. Essa legislação não abrangia outras formas de trabalho que não o serviço doméstico e o fazia, de todo modo, dentro de parâmetros bastante restritos.

A pósa emancipação da coroa portuguesa, o primeiro passo quese deu na direção de construir uma legislação para tratar do trabal ho aconteceu em 183050. A lei, promulgada em 13 de setembro daquele ano, regulamentava sobretudo os contratos de trabal ho que envolvessem imigrantes, delimitando períodos e prazos e adiantamentos de salário. Essa ordenação será suplantada por outra, mais complexa eampla: a lei no 108 , de 11 de outubro de 1837. Esta lei, implantada no contexto dos tratados feitos com a Inglaterra eque se referiam ao fim do tráfico dos escravos, tem mais uma vez os trabalhadores imigrantes agrícolas como seu al vo, não sendo (em princípio) aplicável aos trabalhadores brasileiros. Essa é a legislação que irá reger os contratos de trabalho para estrangeiros até $1879^{51}$.

A primeira lei que versa diretamente sobre a "transição" do trabal ho escravo para o trabalho livre éa lei $n 02040$, de 17 de setembro de $1871^{52}$. A "Lei Rio Branco", ou "Lei do Ventre Livre", éa primeira legislação que trata diretamente da organização do trabalho dos ex-escravos, no contexto 
de um projeto para sua emancipação gradual. Entreoutras coisas, ela libertava imediatamente todos os filhos de ventres escravos nascidos após a data de sua promulgação, estabelecendo as regras para a indenização do trabalho dos menores e o cuidado destas crianças livres e seus compromissos com relação aos senhores sob as quais, em última instância, permaneciam sob os cuidados. A lei dava também consistência jurídica a uma série de práticas correntes na rel ação escravista ${ }^{53}$, como a possibilidade de o escravo acumular pecúlio, de resgatar sualiberdade com o pecúlio acumulado, edas indenizações devidas aos senhores. 0 utra das práticas costumeiras que ganha regulação é aquela em que o escravo se val ia de empréstimo de um terceiro para resgatar sua alforria.

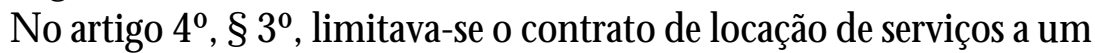
período de sete anos. $N$ o artigo 60, $\S 50$, definia-se que os escravos libertos através da lei seriam "obrigados a contratar seus serviços sob pena de serem constrangidos, seviverem vadios, a trabal har nos estabelecimentos públicos".

A lei de 1871 foi considerada como a peça central de uma estratégia legal que atrelava diretamente a libertação dos escravos à reordenação do trabalho ea transição paraum mercado de trabal ho livre. $N$ ão há dúvida de que a primeira parte da afirmação está correta; por outro lado, o problema da constituição deste "mercado" não foi analisado de outro modo que não através da lógica legal edos debates parlamentares ao redor das leis. Assim, antes de qualquer outra coisa, é a auto-imagem dos legisladores e os seus projetos quevêm à tona. 0 que permanece submerso são os sentidos que os próprios trabal hadores dão ao "mercado" no qual são "livremente" lançados.

Se nos aproximamos dos contratos estando armados dos parâmetros teóricos do "homem econômico", trata-se de arranjos cujo significado central nos está dado de antemão: revelam o jogo universal da barganha que, dentro dos limites de uma relação desigual, conduz os ex-escravos a tirarem o melhor resultado material possível dos novos arranjos de trabal ho $0^{54}$. Se assim não o fizerem, resta concordarmos com a retórica senhorial que via nos ex-escravos homens emulheres despreparados para o mundo, queprecisariam ser educados sobre os seus próprios interesses e para comportaremseracionalmente em suas novas escol has como livres ${ }^{55}$.

As observações anteriores certamente desautorizam essa aproximação. A escolha inversa - isto é, interrogar os contratos em sua positividade - 
podeser, por outro lado, uma experiência importanteno sentido derecuperar as "visões alternativas da vida econômica"56 que poderiam guiar as escol has desses sujeitos em sua nova situação ea definição dos seus "interesse" " 57 . M ais do que isso, é preciso dizer que não basta constatar a existência de uma racionalidadealternativa: épreciso interrogar o seu significado para os sujeitosque o operam. Fazer isso ajudarácertamentea lançar luz sobreo conteúdo concreto que as ações dos ex-escravos poderiam estar atribuindo à "liberdade" que conquistavam.

G ostaria agora detentar um exercício nessa direção, interrogan do uma pequena amostra de "contratos de locação de serviços", quefazem parte de um conjunto maior de contratos e títulos de liberdade que são objeto de uma pesquisa quevenho realizando sobrea experiência do trabal ho "livre" na cidade do $D$ esterro no século $X I X^{58}$.

Em um levantamento inicial, localizei 56 contratos de locação deserviços para o período entre 1849 e $1887^{59}$. Partirei de uma seleção desses registros para- a partir das discussões que propus atéaqui - propor algumas hipótesespara sualeitura.

0 primeiro contrato dessa natureza queencontrei data de 9 defevereiro de 1847 e envolvia um africano liberto de nome Antônio, de $\mathrm{N}$ ação M ocingo. Antônio fazia contrato de locação de serviços a um certo José $M$ anoel deSouza, quelhe havia emprestado a quantia de $263 \$ 610$ (duzentos esessenta etrês mil eseiscentos e dez) réis, com a qual havia resgatado 0 valor de um outro contrato que havia feito anteriormente com Z eferino Fernandes (queéapenas citado nanota). Em troca desse dinheiro, Antônio obrigava-sea prestar 8 anos dos seus serviços ao seu novo patrão, "como se fora seu cativo". Este, por sua vez, comprometia-sea "vesti-lo, sustentá-lo e curá-lo em suas enfermidades" 60 .

Em outro contrato, datado de abril de 1849, uma mulher africana de 25 anos, de nome Thereza, contrata seus serviços com D ona Filisberta Coriolana de Souza Passos. D esta vez, trata-se de uma dívida de cem mil réis que a ex-escrava havia contraído em favor de sua liberdade. Em troca da quantia, comprometia-se com nada menos que 25 anos de seus serviços, aceitando trabalhar "como sefora sua cativa" ea acompanhar sua patroa, ou qualquer um a quem ela indicasse, "para qualquer parte que se destine". Além disso, comprometia-se a não contratar-se com mais ninguém durante 
o período de vigência. Em troca desses compromissos, recebia de sua patroa vestimenta, sustento e cuidados em caso de doença ${ }^{61}$.

$\mathrm{N}$ esses primeiros contratos aparecem vários dos elementos que irão repetir-se na maior parte dos arranjos de trabalho envolvendo ex-escravos ao longo das quatro décadas seguintes: referem-se em primeiro lugar a dívidas invariavel mente contraídas para o pagamento da al forria (ou, como no caso de Antônio, um novo contrato que resgata dívida anterior ligada à alforria); além disso, fazem referência ao compromisso firmado de "servir e respeitar" "como se escravo (ou cativo) fosse" e contém cláusulas que comprometem explicitamente o contratante com o sustento do empregado, além do seu cuidado em caso de doença. Além disso, a relação entreo valor da dívida e o tempo de contrato corresponde de modo nem sempre consistente ao valor de mercado do trabalho contratado.

Como disse antes, al guns desses termos se repetem eacabam por consistir os termos básico dentro dos quais se estabelecerão os contratos nas décadas seguintes. Se pensarmos essas notas como registros que davam fé pública ao resultado de um arranjo que envolvia as estratégias e expectativas de ao menos dois sujeitos, podemos formular al gumas questões.

Em primeiro lugar, ao contrário do que podem parecer à primeira vista, os contratos de locação de serviços não seguem necessariamente um modelo estereotipado. O Ihados individual mente, revelam variaçõese especificidades que apontam diretamente para uma negociação ativa entre as partes. Suas cláusulas abrangem, por exemplo, o cuidado sobrea família, a mobilidade espacial, ou ainda a possibilidade deter al gum controle sobre 0 tempo e os termos do trabalho.

Assim, em 19 de novembro de 1847, Sebastião Cabinda comparece ao cartório do tabelião Lopes Gondim, junto do alemão Pedro Kemper [ou Kimfer], com quem tinha uma dívida de 230\$000 réis, "resto da quantia que lhe havia abonado para sua liberdade". Em troca do dinheiro, comprometia-sea pagar-Iheo montante "nas prestações quelheconvier, podendo fazer quaisquer viagens [... ] para ondelhe convenha, com consentimento do credor, vestindo-se ealimentando-se por sua conta"62.

Arranjo muito diverso daqueleque, em 28 de janeiro de 1848, a preta M aria Leocadia contratou com o C apitão Fernando Antônio Cardoso. N ele, a liberta resgatava a dívida de um contrato feito anteriormente, no valor de $300 \$ 000$ réis. Para pagá-los, contratava seus serviços por um prazo de dez 
anos, obrigando-se ainda: “...na qualidade de curadora natural de sua filha J oaquina, de idade de setemeses mais ou menos, a conservá-la em poder do credor durante o prazo [...] vinte anos, também a contar do primeiro do correntemês, com a obrigação porém do credor alimentá-la, vesti-la edarIhe a precisa educação, de que não exigirá pago algum e ficará este favor compensado com os serviços que a dita menor deverá durante o dito praZo"63.

Em 27 de junho do mesmo ano, Francisco Benguela também resgata um contrato de locação de serviços e faz um novo com Antônio Lopes da Silva. Reconhecendo a dívida de cem mil réis, compromete-se a resgatá-la com seu trabalho por um prazo de três anos e meio: "com a condição de servir [seu patrão] como se fora seu cativo e como tal prestar-lhe toda a obediência eserviços, sendo porém o credor obrigado a alimentá-lo, tratálo e vesti-lo, em cujo prazo de três anos e meio não serálevado em conta o tempo que possa andar fugido ou se recuse a prestar todos os serviços que Ihe forem ordenados" 64 .

Q uase quarenta anos depois, já sob vigência das leis que foram criadas para regular edar fundamento jurídico a este tipo de contrato, reencontramos os arranjos de trabalho que envolviam os ex-escravos no novo mundo da liberdade detrabalho:

Em meados de dezembro de 1884, compareceram ao cartório do escrivão Leonardo J orge C ampos o crioulo liberto J oão Ancelmo e seu patrão, Jacinto Feliciano da Conceição. João declarava uma dívida de duzentos mil réis e fazia um contrato de locação de serviços agrícolas para saldá-la. Trabalharia por quatro anos, na chácara do patrão, "em todos os dias úteis, empregando-se na lavoura, plantação de capim e tudo quanto for relativo aos serviços aplicados à agricultura". 0 locatário comprometiase, por sua vez, com o "sustento e vestuário para o trabal ho do locador assim como fará tratar em suas enfermidades". Enfim, o arranjo definia que "findo o contrato [...] poderá ser renovado conforme dispõe a Lei $\mathrm{n}$ o 2827 de 15 de M arço de 1879 se convier as partes." 65

A crioula $G$ ertrudes, em 8 de maio do ano seguinte, também contratava seus serviços com um certo Fortunato Soncini. Por quatro anos trabaIharia como criada doméstica, como pagamento dos cento e sessenta mil réis que o credor Ihe emprestara. 0 brigava-se a "respeitá-lo e à sua família 
[e] a fazer o serviço doméstico que Ihe for ordenado". Soncini, por outro lado, comprometia-se a dar-Ihe "sustento e vestuário", além de "tratar a devedora em suas enfermidades até o tempo de quinze dias". D epois desse tempo, correria por conta de G ertrudes, as contas de "Botica, M édico e dieta". D eclarava ainda que, "se por ventura ela devedora não se der bem com elecredor ea sua família, poderá se al ugar em qualquer casa defamília, dando-Ihea ele credor mensal mentea quantia de dez mil réis atécompletar o tempo estipulado." 66

Em 26 de janeiro de 1887, éo pardo liberto G ermano que também encontramos alugando seus serviços domésticos à família de Frederico M omm. Resgatava sua dívida de 150\$000 réis comprometendo-se com 4 anos de "seus bons serviços", "compatíveis com sua força e sexo". E m troca do respeito eda obediência devidos (elavrados em nota), recebia o compromisso do novo patrão em "tratá-lo em suas enfermidades quanto estas mesmo excedam de quinze dias, com M édico, Botica, dieta e tratamento sem ônus algum para o devedor"67.

Como interpretar a diversidade expressa nessas notas? 0 que elas revelam sobre as distintas situações em que poderiam se encontrar os ex-escravos ao terem que enfrentar o desafio de articular um arranjo possível de trabalho na condição tão incerta de credor de uma dívida que correspondia, de fato, ao próprio lastro de sua liberdade?

A nova situação não aparecia de forma homogênea para todos: a mãe, provavelmente solteira e com vínculos precários para além da escravidão, vêseforçada a comprometer o seu trabalho eprometer o de sua filha, ainda pequena, pelos vinte anos seguintes, em troca da promessa ambígua devê la receber "a devida educação". A jovem de vinte ecinco anos, praticamente se reescraviza voluntariamente pelos vinte ecinco anos seguintes de sua existência. Como comparar essas situações com aquelas que mostram trabalhadores conseguindo não apenas prazos confortáveis para o pagamento de suas dívidas, como uma tolerância difícil de explicar com cumprimento desses mesmos prazos? Como articular na mesma pergunta essas situações com o caso - certamente excepcional - do crioulo liberto Antônio M artins da Rocha, queem 1869 assinava de seu próprio punho o contrato de locação de serviços em que se comprometea pagar uma dívida de um conto de réis - contraída com o negociante e notável local, Joaquim Augusto do 
Livramento - com nada menos do que oito anos dos seus serviços "de vender água", obrigando-se a entregar mensalmente a quantia de 100 mil réis por todo o período? ${ }^{68} \mathrm{~A}$ situação de um ex-escravo que é capaz de se comprometer a mobilizar recursos desse montante - que pagariam, em oito anos, várias vezes o val or de mercado de um escravo adulto eapto para o trabalho - , ao mesmo tempo em que se amarra a um arranjo detrabal ho draconiano, revela certamente muito da condição paradoxal com que vive seu trabalho "libertado" 69.

O sfios invisíveis que ligam esses fragmentos de histórias não são autoevidentes. A maior partedas perguntas que evocam não podem ser enfrentadas com o fôlego deste artigo. Por hora, entretanto, basta levantar algumas hipóteses que remetem a uma interpretação geral sobre os sentidos que a liberdadede trabalho poderia ter para esses homens emulheres. D eixando de lado, por enquanto, a interrogação sobre as condições específicas desse tempo elugar - a cidade do D esterro no século XIX -, tentarei me deter nos aspectos das experiências desses trabalhadores libertos que podem lançar alguma luz sobre os desafios comuns que estavam presentes no próprio âmago dessa nova condição de "trabalho livre" queenfrentavam.

Ao ser lançado no "mercado" de trabalho em um ambiente urbano, as opções de um ex-escravo, homem ou mulher, eram freqüentemente muito restritas. 0 fato de que a esmagadora maioria das alforrias concedidas na última década da escravidão no principal cartório do D esterro envolvia alguma cláusula de prestação de serviços - seja para o ex-senhor, seja para terceiros através de contratos de locação - parece ser um indicativo importante. Transformar a escravidão em um contrato para o pagamento deuma dívida poderia também significar a tentativa de garantir de algum modo a continuidade de uma ocupação que garantisse a subsistência e uma menor incerteza frente ao futuro. A compensação pecuniária dessetrabal ho - como sugerem, na verdade, os próprios contratos- era certamente subordinada a essa condiç̧ão ${ }^{70}$. Esse parece ser 0 elemento principal que se revela nessas escolhas. Por outro lado, a possibilidade, também presente, de resgatar sua liberdade com um pecúlio acumulado com o trabalho remunerado durante a escravidão podia revelar uma realidade menos desconfortável, queimplicava a existência de víncul os de solidariedade fora da escravidão, o conhecimento de um ofício eo acesso a oportunidades melhores detrabal ho. $M$ as 
essa era apenas uma possibilidade e não uma certeza. E, certamente, não estava ao alcance de todos ${ }^{71}$.

Em cidades como o D esterro, onde as ocupações industriais eram inexistentes ou muito limitadas e onde a produção agrícola (nas freguesias rurais) funcionava com uma mão-de-obra pequena e estável, para aqueles que não conheciam um ofício e não eram empregados como domésticos (ou ainda, no caso do trabalho feminino, em ocupações complementares ao trabal ho doméstico, como lavadeira ou costureira), o "mercado" para os ex-escravos significava antes de tudo as ocupações não especializadas que envolviam o aluguel de suas forças como carregador ou outra ocupação braçal. São ocupações intermitentes, ligadas aos movimentos do porto, às obras públicas, a demandas localizadas de particulares. Incertos, descontínuos e mal pagos, constituem, entretanto, os trabalhos mais prováveis em uma economia local que desconhece completamente aquela "carência de braços" que preocupava os senhores de escravos e empregadores da economia agrícola de exportação ${ }^{72}$.

C omo a dura história dos trabal hadores do século XIX não cansou de ensinar, a "liberdade detrabal ho" não significava o direito ao trabalho. Como em toda economia que se "modernizava”, esta liberava indivíduos "disponíveis", mas não necessariamente "recrutáveis" para o trabalho ${ }^{73}$. 0 resultado disso era, obviamente para a mai oria, uma perspectiva pouco promissora de acesso aos atributos positivos que revestiam a noção de "liberdade" como ideal ehorizonte de expectativa: 0 acesso à propriedade ea um ofício remunerado que permitisse viver dignamente por si, a garantia de poder construir autonomamente seus vínculos de sociabilidade e pertencimento.

A única certeza dos libertos era a de estarem lançados em uma nova situação social marcada pela precariedade, raramente com as ferramentas e recursos necessários para enfrentá-la. Essa precariedade poderia aparecer de modo abrupto e irremediável a cada esquina: através da doença e da indigência, do acidente de trabal ho e da invalidez, da viuvez, da orfandade ou do abandono, da velhice solitária e desassistida.

$\mathrm{N}$ ão se pode abordar minimamente os sentidos dos termos dos contratos a que se submetiam esses homens e mulheres sem levarmos em conta essa realidade básica que se levantava como o horizonte negativo de suas 
escolhas. A redução da incerteza, como nos ensinou Giovanni Levi, é um motor potente para as ações e decisões humanas ${ }^{74}$.

Assim, não devemos nos enganar com a perturbadora contigüidade entre a escravidão e a liberdade que os termos dos contratos parecem sugerir. O s termos que reasseguram ritualmente os vínculos de obediência e dependência aos antigos senhores e aos novos patrões não estão ali como provas de que os ex-escravos não compreendiam o sentido da liberdade que conseguiam, que estavam paralisados pelos val ores imóveis da escravidão e, portanto, incapacitados para viver autonomamente. Ao contrário, acredito queeles revelam coisas bem diferentes.

\section{A luta política dos escravos e os significados da liberdade de trabalho}

Karl Polanyi comparou as classes trabalhadorasinglesas do século XIX aosnativos destribalizados das colônias africanas: a ameaça do "livre comércio" havia destruído seus vínculos sociais, desintegrado seu ambientecultural, desafiado mortalmente suas formas de organizar o mundo ${ }^{75}$. Podemos nos apropriar desse raciocínio fazendo o caminho inverso erepropondo essa analogia para a experiência da escravidão africana: arrancados de suas relações tribais, de sua cultura ede seu território, os africanos foram atiradosna experiência limite de desfiliação social que significou a escravidão eo tráfico atlântico. $\mathrm{N}$ as Américas, entretanto - como mostram exaustivamente as pesqui sas históricas sobre a escravidão - , os escravos não se tran sformaram em seres sem vontade, em objetos inertes entregues à anomia. Eles certamentelutaram contra a escravidão: resistiam, escapavam eserevoltavam de todas as maneiras. M as também, apesar da escravidão e dentro dela, os africanos e seus descendentes lutaram para construir e reorganizar novos vínculos sociais que tornassem a vida suportável. N a ten são constante que caracterizava a relação escravista, foram vítimas e cúmplices da construção de uma ordem social que- mesmo tendo por base a violência ea exploração organizava-se demodo estável, conferindo-Ihes um lugar determinado em uma hierarquia social, numa relação quelhes provia o sustento e cuidados. Sob o domínio paternalista esenhorial, as expectativas dos escravos se organizavam dentro de um horizonte de previsibilidade. A troca de deveres e 
obediência por favores e proteção organizava expectativas de futuro que poderiam incluir o favor da alforria, da possibilidade de casar e constituir família, de conseguir alguma autonomia emesmo tornar-se um agregado. 0 desafio a essa ordem pelo escravo poderia significar o castigo severo, a desagregação dos seus vínculos emesmo a morte, mas essas punições compartilhavam aquelemesmo sentido de previsibilidadeeordem. A "filiação" ou "incorpo-ração" "76 à sociedade escravista configurava uma filiação a uma comunidade, a um território e a uma ordenação hierárquica ${ }^{77}$. Claro que essa era uma forma de pertencimento profundamente opressiva à qual os escravos haviam sido incorporados contra a sua vontade. Ela poderia ser insuportável para alguns, simplesmentetolerável para muitos ou mesmo a única forma de pertencimento que aqueles quehaviam nascido em seu interior conheciam. 0 quenão podemos deixar deconsiderar équeessa era uma forma deorganização social capaz de manter-se fortemente coesae estável.

Subestimar a capacidade de coerência e coesão social da escravidão é um erro. $N$ ão há como entender a persistência da escravidão nas Américase no Brasil sem dar al gum peso ao papel agregativo que as relações sociais produzidas em seu interior possuíam.

A partir do final do século XVIII edurante o século XIX, essa mesma ordem foi profundamente transformada. As novas formas de organização da sociedade, da política, do trabalho e da economia desafiaram as bases intelectuais, morais eeconômicas da escravidão eacabaram por destruí-la ${ }^{78}$. Para os escravos, essas transformações tiveram muitos significados. 0 mais importante deles talvez tenha sido o dar um novo sentido a suas expectativas e lutas. A idéia de "liberdade" adquire um significado novo: passa a carregar a promessa, absolutamente nova, de acesso a direitos universais, que implicavam uma outra forma de pertencimento quenão passaria mais pela subordinação, mas pela idéia de filiar-se a uma comunidade de direitos ededeverescívicos. Entreeles, 0 direito ao trabal ho, mastambém à propriedade, à remuneração digna, ao sustento próprio, ao futuro. D o mesmo modo, o direito deescolher a quais redes de sociabilidadeeinterdependência, a quais relações de solidariedade, a quais vínculos de sentimento perten$\mathrm{cer}^{79}$. Liberdade poderia significar, enfim, poder dar um sentido autônomo a essenovo pertencimento. 
Assim, como lembra Sidney Chalhoub, a "causa política" dos escravos e ex-escravos torna-se mais do que nunca a da liberdade, própria e de seus companheiros ${ }^{80}$. M as é preciso acrescentar que a liberdade era (e é) um objetivo político carregado detensões: pode ser ambíguo como real idadee abstrato como valor. As promessas que o termo carrega não se cumpriam automaticamente com a emancipação e os escravos e libertos sabiam disso. Sob o império da "liberdade" traduzida nos termos da utopia anti-social do mercado, os ex-escravos poderiam encarar uma ameaça tão grande ou maior quea escravidão: arealidade "moderna" da desfiliação social. As vel has coerções e tutelas poderiam ser assim facilmente substituídas pela coerção da miséria.

Libertos daquilo queera, apesar detudo, uma organização social estável eintegrada, os escravos poderiam ser lançados na "individual idade" que se produzia na nova organização do mercado de trabalho. A ameaça da "liberdade" negativa que significava a ausência de ligações e de interdependências se impunha no horizonte de antecipações eescol has daqueles homens emulheres quelutavam e conquistavam sua emancipação e seempenhavam para seinserir deal gum modo nessemundo.

Q uando reencontramos os contratos de locação de serviços, podemos ler neles não as sobrevivências de uma ordem em deterioração, mas o resultado do confronto de expectativas distintas. O s contratos não são, assim, necessariamente evidências de uma subordinação ou um consentimento passivo. Eles lavram e dão fé pública a uma solução de compromisso, ao resultado de uma negociação ativa a partir da qual searticulavam e construíam novas formas de organização social, novos vínculos de dependência e interdependência.

Por um lado, écerto que os patrões e ex-senhores tentavam reorganizar os laços de subordinação e tutela sob a nova forma institucional do contrato. Q ueeles fizessem isso repropondo formas de dominação senhorial análogas às da escravidão não deveria espantar. $\mathrm{N}$ a Europa enas Américas no século XIX, uma das características da reação conservadora às ameaças desagregadoras da sociedade de mercado foi também, na impossibilidade dereconstituir as antigas sujeiçõe ${ }^{81}$, a de tentar impor o paternalismo como plano de governabilidade política ${ }^{82}$. N o B rasil, não eram apenas os antigos escravocratas, criados sob a ideologia da "inviolabi-lidade da vontade 
senhorial"83 que se empenhavam em construir essas tutelas: também - e significativamente- "modernos" empreendedores como o imigrantealemão, comerciantee industrial em Santa C atarina, Carl H oepke, ou ainda o negocianteG ermano Wendhausen, Secretário do Club Abolicionista do D esterro ${ }^{84}$.

Por outro lado, os libertos, a seu modo, tentavam construir ativamentevínculos sociais sarantias suficientes para lidar com a incerteza ea precariedade, reorganizando laços de dependência einterdependência quepermitissem sua filiação a uma ordem social minimamente viável - isto é, que organizasse de al gum modo suas expectativas e conferisse al guma segurança com relação ao futuro (uma estabilidade que, de todo modo, sua situação "liberada" não garantia e, no limite, ameaçava).

É claro que os trabalhadores que se contratavam eram empregados domésticos, cozinheiros, hortelãos, com sorte chapeleiros ou sapateiros. E ram analfabetos em sua esmagadora maioria, dificilmente se articulavam em sindicatos ou associações (ainda queal guns o fizessem, de al gum modo, nasirmandades religiosas). N ão eram "modernos" trabalhadoresindustriais e dificilmente poderíamos chamá-los de "assalariados". Certamente, suas experiênciasnão podem ser consideradas estatisticamente representativas da condição trabalhadora. M as a sua sortee suas lutas, acredito, revelam muito sobre a sortee as lutas dos trabalhadores e pobres em geral. Todos enfrentavam o mesmo inimigo, encarnado pela nova forma de coerção que era a própria condição da nova organização do trabal ho livre: a miséria, a necessidade ea precariedade. Essas eram as mesmas causas quelevavam os trabalhadores pobres da E uropa, da C hina ou da Índia a atravessar os oceanos para tentar uma vida mel hor, trabalhando nas fazendas de cana do $C$ aribe, nas estradas de ferro do 0 este americano, ou nas plantações de café no Brasil. Também eram esses os desafios que davam sentido - eainda dão - às lutas políticas dos trabal hadores para conquistarem o direito à liberdade nos seus própriostermos. 


\section{Bibliografia citada e fontes:}

BRASS, Tom \& M arcel Van Der Linden (eds.). Free and Unfree Labour: The Debate Continues. N ew York: Peter Lang Publishing, 1997.

CARD O SO, Ciro F. (org.). Escravidão e abolição no Brasil: novas perspectivas. Rio de Janeiro, Zahar, 1988.

CASTEL, Robert. As metamorfoses da questão social. U ma crônica do salário. Petrópolis: Vozes, 1998.

CASTEL, Robert; Claude Dirdry \& Bernard Friot. Symposium sur Les métamorphoses de la question sociale: une chronique du salariat, Sociologie du Travail, no 43, 2001, pp. 235-263.

CH ALH O UB, Sidney, Visões da Liberdade. U ma história das últimas décadas da escravidão na Corte. São Paulo: Companhia das Letras, 1990.

CH ALH O UB, Sidney. A enxada e o guarda-chuva: a luta pela libertação dos escravos e a formação da classe trabalhadora no Brasil (trabalho apresentado no XXI Simpósio N acional da AN PUH, N iterói, junho de 2001, mimeo.)

CHALHOUB, S. et alli (org.) Artes e ofícios de curar no Brasil. Capítulos de história social. Campinas: Ed. U nicamp, 2003.

CONRAD, Robert. Os últimos anos da escravatura no Brasil. Rio de Janeiro: Civilização Brasileira, IN L, 1975.

CO O PER, F., T. H olt. \& R. Scott. Além da escravidão: Investigações sobre raça, trabalho e cidadania em soci edades pósemancipação. (Prefácio de $\mathrm{H}$ ebe $\mathrm{M}$ attos), Rio de Janeiro: Civilização Brasileira, 2005.

COSTA, Emília Viotti da. Da senzala à colônia. São Paulo: Liv. Ciências H umanas, 1982 (1966).

CRAT O N, M ichael. Reembaralhando as cartas: a transição da escravidão para outras formas de trabalho no Caribe britânico (c. 1790-1890), Estudos AfroAsiáticos, n. 28, 1995, pp. 31-83.

DAVIS, David Brion. The problem of Slavery in the Age of Revolution 1770 1823. N ew York/O xford: O xford University Press, 1999.

DUM ONT, Louis. H omo aequalis. Gênese e plenitude da ideologia econômica. Bauru: Edusc, 2000. 
FLORENTIN O, M anolo \& J. R. Góes, A paz nas senzalas. Famílias escravas e tráfico atlântico, Rio de Janeiro, c. 1790 - C. 1850. Rio de Janeiro: Civilização Brasileira, 1997.

FLORENTIN O, M anolo \& João Fragoso. 0 arcaísmo como projeto. M ercado atlântico, sociedade agrária e elite mercantil em uma economia colonial tardia. Rio de Janeiro, c. 1790 - c. 1840. 4a ed. Rev. e ampl. Rio de Janeiro: Civilização Brasileira, 2001.

FRAN CO, M aria Sílvia de Carvalho. H omens livres na ordem escravocrata. 3a ed. São Paulo: Kairós, 1983.

GEBARA, Ademir. 0 mercado de trabalho livre no Brasil (1871-1888). São Paulo: Brasiliense, 1986.

GLICKSTEIN , Jonathan A. C oncepts of free labor in Antebellum America. N ew H aven: Yale University Press, 1995.

GRENDI, Edoardo. Polanyi, dell'antropologia economica alla microanalise storica. M ilano: Etas Libri, 1978.

H IRSCH M AN, Albert. Paixões e interesses. Argumentos políticos a favor do capitalismo antes do seu triunfo. Rio de Janeiro: Record, 2002.

H O LT, Thomas C. The Problem of Freedom. Race, Labor, and Politcs in Jamaica and Britain, 1832-1938. Baltimore and London: Johns H opkins University Press, 1992.

KOWARICK, L. Trabalho e vadiagem: a origem do trabalho livre no Brasil. São Paulo: Brasiliense, 1987.

LAM O U N IER, M aria Lúcia. D a escravidão ao trabalho livre: a lei de locação de serviços de 1879. Campinas: Papirus, 1988.

LARA, Sílvia H unold (org). Escravidão (numero especial da Revista Brasileira de H istória, vol. 8, no 16, março/agosto 1988.

LARA, Silvia H unold. Escravidão, cidadania e história do trabal ho no Brasil, Projeto História, no 16, 1998, pp. 25-38.

LEPETIT, Bernard. Le travail de I'histoire, Annales HSS, mai-juin 1996, oㅡ 3, pp. 525-538.

LEVI, Giovanni. A herança imaterial. Trajetória de um exorcista no Piemonte do século XVII. Rio de Janeiro: Civilização Brasileira, 2000.

M ATTOS, H ebe M aria. D as cores do silêncio: os significados da liberdade no Sudeste escravista. Brasil, século XIX. Rio de Janeiro: N ova Fronteira, 1998 (1995). 
MATTOS, H ebe M aria \& Ana M aria Rios. 0 pós-abolição como problema histórico: balanços e perspectivas. Topoi, volume 5, no 8, janeiro-junho 2004, pp. 170-198.

M ATTOS, H ebe M aria \& Ana M aria L. Rios. M emórias do cativeiro: família, trabalho e cidadania no pós abolição. Rio de J aneiro: Civilização Brasileira, 2005. M EN D O N ÇA, Joseli M aria N unes. Entrea mão e os anés. A lei dos sexagenários e os caminhos da abolição no Brasil. Campinas: Edunicamp/C ecult, 1999.

M OREIRA, Paulo Roberto S. O s cativos e os homens de bem: experiências negras no espaço urbano. Porto Alegre, 1858-1888. Porto Alegre: EST Edições, 2003. PECK, Gunther. Reinventig Free Labor: Padrones and Immigrant Workers in the N orth American West, 1880-1930. N ew York: Cambridge U niversity Press, 2000. PEN A, Eduardo Spiller. 0 jogo da face. A astúcia escrava frente aos senhores e à lei na Curitiba Provincial. Curitiba: Aos Q uatro Ventos, 1999.

PIN H EIRO, Paulo Sérgio (ed.). Trabalho Escravo, Economia e Sociedade. Rio de Janeiro: Paz e Terra, 1984.

POLANYI, Karl (with collaboration of Abraham Rotstein). Dahomey and the slave trade. An analysis of an archaic economy. Seattle and London: University of Washington Press, 1966.

PO LAN YI, Karl. A grande transformação. As origens da nossa época. 7ạ edição, Rio de Janeiro: Campus, 2000.

REIS, João José \& Eduardo Silva. N egociação e conflito. A resistência negra no Brasil escravista. São Paulo: Companhia das Letras, 1989.

SLEN ES, Robert. Na Senzala uma Flor. Esperanças e recordações na formação da família escrava, Brasil Sudeste, século XIX. Rio de Janeiro: N ova Fronteira, 1999. STAN LEY, Amy D ru. From Bondage to Contract. Wage Labor, M arriage, and the $M$ arket in the Age of Slave Emancipation. Cambridge ( $M$ as.): Cambridge University Press, 1998.

STEIN FELD, Robert. Coercion, contract and freelabor in theN ineteenth Century. Cambridge (M as.): Cambridge University Press, 2001.

STEIN FELD, Robert. The Invention of Free Labor: The Employment Relation in English and American Law and Culture Chapel Hill (NC): North Carolina University Press, 1991.

TH OM PSO N, E.P. Costumes em Comum. Estudos sobre a cultura popular tradicional. São Paulo: Companhia das Letras, 1998. 
TURNER, M ary (ed.). From Chattel Slaves to Wage Slaves. The D ynamics of Labour Bargaining in the Americas. Kingston/Bloomington \& Indianapolis/ London: Ian Randle/Indiana University Press/James Currey, 1995.

\section{Fontes:}

O rdenações Filipinas, vols. 1 a 5; Edição de Cândido M endes de Almeida, Rio de Janeiro de 1870, versão digitalizada: http://ara.ci.uc.pt/ihti/proj/filipinas/ ordenacoes.htm

Livros de N otas do 10 e 20 O fício de N otas do D esterro (século XIX) - Atual 1o O fício de $\mathrm{N}$ otas e 3 o de Protestos de Florianópolis (Cartório Kotzias).

\section{Notas}

${ }^{1} \mathrm{~A}$ noção de "interesse", como nos lembraAlbert $\mathrm{H}$ irschman, assumeum caráter quase que estritamenteeconômico a partir do século XVIII. A história dessa transformação está discutida por eleem Paixõeseintereseses. Argumentospolíticosa favor do capitalismo antesdo seu triunfo. Rio deJ aneiro: Record, 2002.

2 PO LANYI, K arl. A grandetransformação. Asorigensda nossa época. 7 a edição, Rio deJ aneiro: Campus, 2000 (1944), p. 89. As páginas seguintes se apóiam amplamente nas análises desenvolvidasnestelivro.

${ }^{3}$ Sigo, maisuma vez, a discussão de Polanyi contida no conjunto de A grandetranformação. O stermos: "encapsulado" e "desencapsulado" traduzem ostermosembedded/disembedded, que são centrais natipologiateórica de Polanyi (cf. GREN D I, Edoardo. Polanyi dell'antropol ogia economica alla microanalise storica. M ilano: Etas Libri, 1978). Essa escolha de termos é distinta daqueleutilizada pela tradução brasileira citada, queeu utilizo para todo o resto.

${ }^{4} \mathrm{O}$ livro de $\mathrm{H}$ irschman, citado na nota 1 , serve como uma útil introdução ao tema. Ver também o livro de LouisD U M O N T , H omo aequalis. Gêneseeplenitudeda ideologia econômica. Bauru: Edusc, 2000.

${ }^{5}$ Cf. PO LAN YI, op. cit. p. 18.

${ }^{6} \mathrm{O}$ triunfo intelectual do modelo liberal foi muito mais extenso eduradouro que qualquer triunfo político ou econômico quetal modelo tenha tido. É preciso ter isto no horizonte quando analisarmos as posições políticas, os planos reformadores, ou os cálculos de eficáciados agentes sociais que tinham esse model o no seu horizonteracional.

${ }^{7}$ U ma referência fundamental permanece sendo a discussão de E.P. T hompson sobre 0 sentido das lutas camponesas na Inglaterra do final do século XVIII contra a imposição das regras demercado paraa regulação do preço dos gêneros: Costumesem Comum. Estudossobrea cultura popular tradicional. São Paulo: Companhia das Letras, 1998, principal mentecapítulos 4 e5 (A economia moral da multidão ingl esa no séculoXVIII eEconomia moral revisitada, pp. 150-266). 
${ }^{8} \mathrm{C}$ f. CAST EL, Robert. Asmetamorfoses da questão social. U ma crônica do salário. Petrópolis: Vozes, 1998, p. 170.

${ }^{9}$ Ibid, p. 155.

${ }^{10}$ Essa é, pelo menos, a imagem que os defensores do livre mercado fizeram do trabalho forçado. Podemos constatar o quanto de "retórica" hán estaimagem ao lembrarmos daimportância crescentequeo trabalho escravo tevenas colônias do N ovo M undo durantea própria ascensão da economia liberal. Em economias onde a mão-de-obra "não estava prontamente disponível no lugar certo, pelo preço certo ou insuficientemente afastada das relações nãocapitalistas de produção" - como no caso daAmérica-, o trabal ho escravo eforçado era usado largamenteno mesmo momento em que, na Europa, o sistema capitalista do trabal ho assalariado estava amadurecendo (Cf. CO O PER, F., T. H olt \& R. Scott, Introdução, In: Além da escravidão. Investi gaçõessobreraça, trabal ho ecidadania em sociedadespósemanci pação. Rio de Janeiro: Civilização Brasileira, 2005, p. 73).

${ }^{11}$ Cf. CASTEL, op. cit., p. 44.

${ }^{12} \mathrm{Cf}$. CAST EL, op.cit., p. 212.

${ }^{13}$ Para uma discussão sobre o significado do pauperismo, ver os capítulos 9 e 10 deA grande tranformação e o capítulo 5 do livro de Robert Castel. Este sociólogo, em particular, discute como os discursos sobre pauperismo - querepresenta osoperários como moralmente degradados- não representa apenas o medo dos abastados frente aos novos conflitos sociais, enem apenas o etnocentrismo ou o puro preconceito anti-operário (ainda quetambém o seja), mas revela algo da realidade sociológica daquela sociedade: "a novidade[o pauperismo] édevidaa tomada de consciência de uma condição trabal hadora detal modo degradada, quecoloca populaçõesinteiras nas fronteiras da associabilidade" (CAST EL, op. cit., p. 289).

${ }^{14}$ Cf. CAST EL, op. cit., p. 219.

${ }^{15}$ Cf. CAST EL, op. cit., p. 221.

${ }^{16} \mathrm{Cf}$. CAST EL, op. cit. p. 284. É essetambém o sentido da afirmação deque "avagabundagem representaa essêncianegativa do assalariado", pois, "o vagabundo éum assalariado 'puro' no sentido em que, falando demodo absoluto, só possuía força deseus braços. É a mão-deobra em estado bruto. M asélheimpossível entrar numarelação sal arial para vendêla. Sob a forma da vagabundagem, a condição deassalariado, poder-seia dizer, 'chega ao fundo', éo grau zero da condição salarial: um estado impossível (masque, entretanto, existiu em carnee osso para centenas demilhares de exemplares), que condena à exclusão social. Porém, estecasolimitesublinha traçosque, naépoca, a maioria dassituações salariais partilhou." (ibid. p. 149).

${ }^{17}$ Cf. CASTEL, op. cit. p. 250.

${ }^{18}$ Cf. PO LAN YI, op. cit. p. 298.

${ }^{19}$ Cf. CAST EL, op. cit., p. 263.

${ }^{20}$ Id. Ibid.

${ }^{21}$ PO LAN YI, op. cit., p.90. 0 conceito de "mercadoria" écentral aqui. C omo nos lembra Polanyi, éatravés deleque "o mecanismo do mercado seengrena aos várioselementos da vida 
industrial. Asmercadorias são aqui definidas, empiricamente, como objetosproduzidos para a vendano mercado; por outro lado, osmercadossão definidos empiricamente como contatos reais entre compradores evendedores. Assim, cada componente da indústria aparece como al go produzido para avenda, poissó então podeestar sujeito ao mecanismo da ofertaeprocura, com a intermediação do preço. $\mathrm{N}$ a prática, isto significa quedevehaver mercado para cadaum doselementos daindústria; quenesses mercadoscadaum desseselementoséorganizado num grupo de oferta eprocura". (op. cit, p. 93, grifo meu).

${ }^{22}$ Cf. PO LAN YI, op. cit., pp. 94- 95.

${ }^{23}$ Cf. CAST EL, op. cit., p. 255. Aqui, mais uma vez, as análises de Polanyi e Castel se complementam. Podemos dizer queambos compartilham atese central dePolanyi, queé perseguida sistematicamente em A grande tran formação: “N ossa tese é que a idéia de um mercado auto-regulável implicava uma rematada utopia. U ma tal instituição não poderia existir em qual quer tempo sem aniquilar a substância humana enatural da sociedade; ela teria destruído fisicamenteo homem etransformado seu ambientenum deserto." (Cf. PO LAN YI, op.cit., p. 18).

${ }^{24}$ Cf. CASTEL, op. cit., p. 273.

${ }^{25}$ Cf. CASTEL, op. cit., p. 44.

${ }^{26}$ Cf. CASTEL, op. cit., p. 45.

${ }^{27} \mathrm{~A}$ tentativa de compreen der esta nova miséria que surge com a industrialização estátambém, deresto, na própria origem da teoria social moderna: do liberal ismo econômico ou 0 darwinismo social ao positivismo ou o marxismo. Polanyi aponta aligação entreo pauperismo, a economia política e essa "descoberta da sociedade" que fundamenta a busca por uma explicação "do verdadeiro significado tormentoso da pobreza" (Cf. PO LAN YI, op. cit. p. 153). A solução que, garantindo as premissas da economia clássica, vênanatureza a explicação da sociedade (tran sformando as leis do mercado em leis naturais), começa a assombrar as ciências do homem também aí. 0 darwinismo social, o naturalismo, o racismo "científico" são exemplos disso. 0 marxismo como pensamento social, por outro lado, éuma tentativa (malograda do ponto devistateórico, deacordo com Polanyi) dereintegrar a sociedadeno mundo humano. Parauma discussão mais extensa (ain da que freqüentementeimpressionista) desses temas, ver os capítulos 9 e 10 deA grandetransformação.

${ }^{28} 0$ conceito de "desfiliação social" éusado por Robert C astel para descrever uma situação social definida pela vulnerabilidade da posição de um indivíduo com relação às redes de integração social, queenvolvem desde o pertencimento precário a uma comunidade ou rede de sociabilidade, atéa precariedade do trabalho ea fragilidadedos vínculossócio-culturais. 0 conceito éfluído, mas central em suasanálises sobrea constituição da "sociedade salarial" no século XIX esuas especificidades. Para uma discussão extensa sobre o tema, ver aintrodução e o primeiro capítulo deAsmetamorfosesda questão sodal (pp. 21-93). Ver também: CAST EL, R. et alli. "Symposium sur Lesmétamorphosesdela question sodiale unechroniquedu salariat", Sociologie du travail, no 43, 2001, pp. 235-263.

${ }^{29} \mathrm{O}$ queésugerido, por exemplo, pelo trabal ho dePECK, G unther. Reinventing freelabor: Padrones and immigrant workers in the N orth American West, 1880-1930 (N ew York:

Topol, v. 6, n. 11, jul.-dez. 2005, pp. 289-326. 
Cambridge U niversity Press, 2000), que mostra que em pleno oeste americano, em um espaço e em um tempo que a historiografia dos Estados U nidos costuma considerar paradigmático do espírito empreen dedor americano, a noção detrabalho livrecomportava ambigüidades importantes, erelações de trabal ho centradas nasfiguras dos padronesebaseadasna coerção etutela eram empreendidas não por rudeseprimitivosempregadores, mas por empreendedores modernos.

${ }^{30} \mathrm{Cf}$. ST EIN FELD, Robert. Coercion, contract and freelabor in the $\mathrm{N}$ ineteenth Century. C ambridge(M as.): C ambridgeU niversity Press, 2001, p. 2. Para uma discussão anterior de Steinfeld sobreahistóriajurídica do "trabalho livre", ver o seu Thelnvention of FreL Labor: The Employment Relation in English and American Law and Culture Chapel H ill (NC): N orth Carolina U niversity Press, 1991.

${ }^{31}$ Steinfeld chamaa atenção paraa necessidade dese construir uma visão "anti-essencialista" dastipologiascom queselida com aquestão do trabalho: "U ma dificuldade com a sabedoria convencional éque ela retifica os tipos de trabalho, trata-os como 'coisas' com um conteúdo fixo, ao invés detratálos como práticas sociais/legais quepodem ser construídasem uma série demaneiras distintas" (Coercion, contract and frelabor, cit. p. 33).

${ }^{32}$ BRASS, Tom. Freeand unfreelabour: thedebatecontinues In: BRASS, Tom \& M arcel Van D er Linden (eds.) F ree and U nfree Labour: T he D ebate C ontinues. N ew York: Peter Lang Publishing, 1997, p. 12. Brass discute nesta passagem da introdução os artigos de Robert Steinfeld eStanley Engerman publicadosno volume.

${ }^{33}$ Sobre isso ver os artigos publicadosna primeira parte (N egotiating Slavery) do livro organizado por TU RN ER, M ary: From Chattel Slaves to Wage Slaves. The D ynamics of Labour Bargaining in theAmericas. Kingston, Bloomington and Indianapolis, London: Ian Randle, Indiana University Press, James C urrey, 1995.

${ }^{34} \mathrm{Cf}$. GLICKST EIN , Jonathan A. Concepts of freelabor in Antebellum America. N ew H aven: Yale University Press, 1995, p. 2. E uma afirmação como essa, poderíamos acrescentar, éobviamente válida do mesmo modo para outroslugares, como o Brasil, por todo o século XIX.

${ }^{35}$ Ver sobre isso: C O O PER , F., T. H olt, \& R. Scott, Introdução, in Além da escravidão... cit. Ver também, especialmente, 0 artigo deFrederick C ooper no mesmo volume: "C ondições análogasà escravidão", pp. 201-279.

${ }^{36} \mathrm{Cf}$. C O O PER, F., T. H olt, \& R. Scott, Introdução, in Além da escravi dão... cit., p. 45. Os autores destelivro inspirador colocam o problemada "liberdade" em termosquevalem a pena mencionar: a "liberdadenão éum estado natural. É um construto social, um conjunto de valorescoletivamentecomuns, reforçado pelo discurso ritual, filosófico, literário ecotidiano. A liberdade tem uma história que contém noções distintas cuja própria fusão numa tradição histórica específica étão importantequanto a tensão entreelas." (pp. 51-52).

37 "Em torno de 1890, as elites inglesas desenvolveram sua própria definição do 'trabal ho livre'. 'T heE conomist anotou em 1891... que'a controvérsia geral sobreo trabalho está para transformar-seamplamentesobreos respectivos direitose deveres dos trabal hadores livrese dos sindicalistas' - os trabal hadores livres sendo definidos como todos aqueles quequeriam fazer seus próprios contratos independentes com seus empregadores, sem levar em conta a 
posição do sindicato.' John SAVILLE, TradeU nionsand F ree Labour: TheBackground to the Taff Vale D ecision, In: Essays in Labour H ittory, ed. Asa Briggs and John Saville (London, 1967), 319." Apud: ST EIN FELD , Robert. Coercion, contract and freelabor in thenineteenthcentury, cit. p. 14, nota 27.

${ }^{38}$ PO LAN YI, Karl (e Abraham Rotstein). D ahomey and the savetrade. An analysis of an archaic economy. Seatle and London: U niversity of Washington Press, 1966, p. xvii.

${ }^{39}$ As referências aqui são inúmeras. $\mathrm{N}$ o caso do Brasil, para fazer uma lista (necessariamente incompleta) dostrabal hosmaisinfluentes, podemoscitar: CARD O SO , Ciro F. (org.) Escravidão eabolição no Brasil: novas perspectivas Rio de Janeiro, Zahar, 1988; LARA, SílviaH . (org) Escravidão (número especial da Revisa Brasileira deH istória com vários artigos sobreo tema, vol. 8, no 16, março/agosto 1988); REIS, João J osé\& Eduardo Silva, N egociação econflito. A resistência negra no Brasil escravista. São Paulo: Companhia das Letras, 1989; CH ALH O U B, Sidney, Visõesda Liberdade. U ma hisória dasúltimas décadas da escravidão na Corte. São Paulo: Companhia das Letras, 1990; M AT TOS, H ebeM aria, D ascoresdo silêncio: ossignificadosda liberdadeno Sudesteescravista. Brasil, século XIX, Rio deJ aneiro: N ova Fronteira, 1998 (1995); FLO REN TIN O , M . eJ. R. Góes, A paz nassenzalas. Famíliasescravasetráfico atlântico, Rio deJ aneiro, c. 1790 - c. 1850. Rio deJ aneiro: Civilização Brasileira, 1997; SLEN ES, Robert. $\mathrm{N}$ a Senzala uma Flor. Esperançase recordaçõesna formação da família escrava, B rasil Sudeste, sécul oXIX. Rio deJ aneiro: N ovaFronteira, 1999.

${ }^{40} \mathrm{~N}$ esse sentido, vale também para o Brasil aquilo que os autores de Além da escravidão afirmam para a historiografiaamericana sobrea escravidão: 0 "trabal ho livre", dessemodo, acabava por ser definido apenas como "o fim da coação, não como uma estrutura decontrole da mão-de-obra que precisasseser analisada a seu próprio modo", cf. C O O PER, F., T. H olt, \& R. Scott, Introdução, cit. p. 42. E acrescentam: " 0 conceito desociedades escravistasinspirou eencorajou o estudo de uma totalidade: uma economia política, sua legitimação ideológicae suas conseqüências ecológicas eculturais, tudo, dealgum modo, iluminado por um conjunto específico de relações sociais detrabalho e, por suavez, iluminando-0. Não estamosacostuma dosa pensar em trabal ho livre, e 'sociedadeslivres' do mesmo modo" (ibid. pp. 43-44, grifo meu).

${ }^{41}$ D ois importantes trabal hos que, no Brasil, tematizaram o problema do "significado da liberdade" diretamente- o deSidney Chalhoub e o deH ebeM attos citados duasnotas atrás - fazem isso sem enfrentar demodo integral, entretanto, o sentido da "liberdade detrabalho". $M$ ais recentemente, o problemahistoriográfico do pós-abolição vem sendo objeto deestudos inspiradores. Ver, por exemplo, os trabalhosrecém-lançados: M ATTOS, H ebeM aria \& Ana M aria Rios. 0 pós abolição como problema histórico: balançoseperspectivas. Topoi, volume5, n8, janeiro-junho 2004, pp. 170-198; o já citado Além da escravidão, cit., recém-traduzido no Brasil com um importante prefácio de H ebeM attos; eainda: M AT TO S, H ebeM aria eAna Lugão Rios. M emórias do cativei ro: família, trabalho e cidadania no pós abolição. Rio de J aneiro: Civilização Brasileira, 2005.

${ }^{42}$ Aqui, mais umavez, as referências são variadas. Algumas dasmaisimportantes são: CO STA, Emília Viotti da. D a senzala à colônia, São Paulo: Liv. Ciências H umanas, 1982 (1966); PIN H EIRO , P. S. (ed.). Trabalho Escravo, Economia eSociedade. Rio deJaneiro: Paz eTerra,

Topol, v. 6, n. 11, jul.-dez. 2005, pp. 289-326. 
1984; GEBARA, Ademir. 0 mercado de trabalho livre no Brasil (1871-1888). São Paulo: Brasiliense, 1986; KOWARICK, L. Trabalho evadiagem: a origem do trabal ho livreno Brasi. São Paulo: Brasiliense, 1987; LAM O U N IER, M . L. D a eccravidão ao trabalho livre: a lei de locação de serviçosde1879. Campinas: Papirus, 1988.

${ }^{43}$ LARA, Silvia H . Escravidão, cidadania ehistória do trabalho no Brasil, Projeto H istória, no 16, 1998, pp. 25-38.

${ }^{44} \mathrm{C}$ omo por exemplo, no trabalho clássico deFRAN CO , M aria Sílvia de Carvalho - $\mathrm{H}$ omens livresna ordem escravocrata, 3a edição, São Paulo: Kairós, 1983 - que continua a influenciar as análises sócio-históricas a esse respeito. Para uma crítica ponderada a esse trabal ho euma visão alternativa sobreal guns deseustemas, ver M AT TO S, H ebeM . D ascoresdo siêncio... cit. ${ }^{45} \mathrm{M}$ anolo Florentino eJ oão Fragoso mostraram, em contraste, quea "racionalidade" daclasse senhorial não era efetivamentehomogênea epodia abraçar, em pleno século XIX, um projeto amplamente "arcaico" (não necessariamenteno sentido val orativo, masno sentido polanyiano de "economia arcaica"): 0 arcaísmo como projeto. M ercado atlântico, soci edade agrária eel ite mercantil em uma economia colonial tardia. Rio de Janeiro, c. 1790 - c. 1840. 4a ed. rev. e ampl. Rio de Janeiro: Civilização Brasileira, 2001.

${ }^{46} \mathrm{Assim}$, partindo dos pressupostos de como a sociedadebrasileira deveria ser, tenta-seanalisar aquilo que elaé(ou foi). Ao fazer isso, constrói-seuma armadilha quearriscafazer a interpretação andar em círculos.

${ }^{47}$ C omo mostra eloqüentemente Amy D ru Stanley no seu livro From Bondageto C ontract. Wage labor, marriage and the market in the age of slave emanci pation. $C$ ambridge ( $M$ as.): C ambridgeU niversity Press, 1998 (sobretudo o primeiro capítulo). Sobre as questões em torno do significado da liberdadee do contrato no C aribeinglês pósemancipação, ver o artigo deT homas C. H olt no já citado Além da liberdade(2005), além do seu livro, TheProblem of Freedom. Race, Labor, and Politcsin Jamaica and Britain, 1832-1938. Baltimoreand London: JohnsH opkins U niversity Press, 1992.

${ }^{48}$ Ademir G ebara e M aria Lúcia Lamounier (ver nota 43) desenvolvem esse argumento anal isando, respectivamente, a Lei $\mathrm{n}-2.040$, de28/09/1871 (a Lei Rio Branco) eo D ecreto no 2.827, de 15/03/1879 (Lei Sinimbu).

${ }^{49}$ T ítulos XXIX aXXXVI (O rdenaçõesFilipinas, vols. 1 a5; Edição de C ândido M endes de Almeida, Rio deJ aneiro de1870, versão digitalizada: http://ara.ci.uc.pt/ihti/proj/filipinas/ ordenacoes.htm).

${ }^{50}$ Essa lei é de 13/09/1830. Sobre a história da legislação sobre o trabal ho no período escravista, ver G EBARA, 0 mercado detrabalho livreno Brasil (1871-1888), cit. (principalmenteo capítulo 2). Estaéa bibliografia principal para os apontamentos sobre o tema feitos nesteparágrafo.

${ }^{51} \mathrm{Q}$ uando é editada a lei sobre a locação de serviços agrícolas. Ver LAM O U N IER, D a escravidão ao trabalho livre, op. cit.

${ }^{52}$ Lei no 2.040, de28/09/1871. Collecção dasL és do Imperio do Brasil de1871, Tomo XXXI, Partel (Rio deJaneiro, 1871), pp. 147.151 (referências tiradas deC O N RAD, Robert. Os 
últimosanos da escravatura no Brasil. Rio deJ aneiro: Civilização Brasileira, IN L, 1975, que transcreveintegralmentea lei no seu apêndicell, pp. 366- 369).

${ }^{53} \mathrm{E}$, dessemodo, a principal novidadequeintroduzia na relação senhor/escravo eraa legalidadede práticas queantes eram apenas costumeirase cuja validade dependia, antes detudo, da vontade senhorial. D e todo modo, esse foi certamente um elemento desestabilizador da ordem senhorial sobrea qual assentavaas rel ações escravistas. Parauma discussão dos significados da lei de 1871 com relação às práticas costumeiras da escravidão, ver de Sidney CH ALH OUB, Visõesda liberdade(cit.).

${ }^{54}$ Esseéo sentido exclusivo quese dá aos contratos dos escravos se seguirmos, por exemplo, o que diz M ary Turner sobreos termos debarganha disponíveis para os escravos: Falando de um "novo filão deresistência do trabal hador escravo" queos estudos da escravidão apontavam (para além da tradicional dicotomia "acomodação" e "rebelião"), a "negociação" dos escravos, deacordo com ela, revelava "uma população escrava trabal hadora consciente do valor do seu trabalho edeterminada a ganhar o melhor retorno por ele" "Introduction" (by M ary Turner) In: From Chattel Slaves to WageSlaves, cit. p. 2. Esse livro éuma prova de que mesmo um conjunto formidável detrabal hos que tematizam criticamenteo problema da negociação dos escravos pode cair nas armadilhas montadas pelo paradigma do "mercado", mesmo quando tenta explicitamentese desvencilhar dele.

${ }^{55}$ Ver sobre isso a discussão de oseli M aria N unes M EN D O N ÇA - Entrea mão eosanés A lei dossexagenári oseoscaminhosda aboli ção no Brasil. Campinas: Ed. U nicamp/Cecult, 1999 (sobretudo o primeiro capítulo, pp. 45-135).

${ }^{56}$ Sobreisso, ver al ntrodução deAlém da escravi dão, cit., principalmentep. 70. Sobreuma discussão acerca da "visão alternativa da vida econômica" dos escravos elibertos jamaicanos, confrontadas com as expectativas dos oficiais coloniais britânicos no pós-emancipação, ver H O LT , Thomas, "A essência do contrato", In: Além da escravidão, cit. pp. 89-129.

${ }^{57}$ Além disso, vale partir da consideração de Edoardo G rendi de que "pensar a sociedade econômica não deve necessariamente contemplar a exigência de uma abstração da esfera econômica do 'resto'" (GREN DI, Polanyi... op. cit., p. 3). Em outras pal avras: entendendo que essas "visões alternativas" não se referem a uma "economia" abstraída da cultura e das relaçõessociais.

${ }^{58} \mathrm{~A}$ amostra quetrato a seguir contém dados levantados pela minha própria pesquisa, assim como pelas pesqui sas deC lemente G entil Penna eTamel usa C eccato, a quem agradeço.

${ }^{59}$ Esta amostra foi retirada deuma pesquisa em andamento nos livros denotas do $\mathrm{C}$ artório do 2 ○ O fício de $\mathrm{N}$ otas deFlorianópolis. Estecartório contém uma sériebastantelacunar delivros quepertenciam ao $1^{\circ}$ e 2º 0 fício deN otas do D esterro no século XIX. A amostraéresultado do levantamento completo de todas as notas registradas nos livros seguintes: livro 11 do $1^{\circ}$ O fício de $\mathrm{N}$ otas (1886-7), 20 0 fício de N otas: livros 11 (1847-1848), 12 (1849), 14 (1853), 22 (1859), 23 (1861), 29 (1866), 31 (1868-9), 33 (1870), 58 (1884), 59 (1885), 60 (1885-86), 61 (1886-87), 62 (1887).

Topol, v. 6, n. 11, jul.-dez. 2005, pp. 289-326. 
60 “Escritura deloucação deserviços quefaz o preto liberto Antônio deN ação M ocingo aJ osé M anoel de Souza...", Livro 11 do 20 0 fício de N otas da Cidade do D esterro (1847-1848). (escrivão João Antônio Lopes G ondim), fls. $4 \mathrm{e} 4 \mathrm{v}$.

${ }^{61}$ "Escriptura de loucação de serviços que faz a preta liberta Theresa, a D ona Filisberta Coriolana de Souza Passos", Livro 12 do 200 fício de N otas da Cidade do D esterro (1849) (escrivão J oão Antônio LopesG ondim), fls. 10 e10v.

62 “Escriptura de loucação de serviços que faz o preto liberto Sebastião $C$ abinda a Pedro [Kemper]", Livro 11 do 2ㅇ O fício de N otas da Cidade do D etterro (1849) (escrivão João Antônio Lopes G ondim), fls. 31ve32.

63 "Escriptura de loucação de serviços que faz a preta liberta M aria Leocadia ao C apitão Fernando Antônio C ardoso", Livro 11 do $2^{\circ} 0$ fício deN otasda Cidadedo D esterro (1849) (escrivão J oão Antônio Lopes G ondim), fls. 41, 41v e 42.

64 “Escriptura de loucação de serviços que faz o preto liberto Francisco Benguella a Antônio Lopes da Silva", Livro 11 do 200 fício deN otas da Cidadedo D esterro (1849) (escrivão J oão Antônio Lopes Gondim), fls. 54 e54v.

65 “Escriptura de contracto de lou cação de serviços quefaz o crioulo liberto J oão Ancelmo a Jacinto Feliciano da Conceição como abaixo se declara" Livro 58 do 200 fício deN otas da Cidadedo D eterro (1884) (escrivão Leonardo JorgedeC ampos), fls. 27v, 28 e28v.

66 “Escriptura de contracto de loucação de serviços quefaz a crioula $G$ ertrudes a Fortunato Soncini como abaixo sedeclara", Livro 59 do 200 fício deN otasda Cidadedo D esterro (1885) (escrivão Leonardo Jorge deC ampos), fls. $5 v$ e6.

67 "E scriptura de contracto de loucação de serviços que presta o pardo liberto G ermano a Frerderico M omm", Livro 62 do 200 fício deN otas da Cidadedo D esterro (1887) (escrivão Leonardo Jorge de ( ampos), fls.48 e48v.

68 "Escriptura deloucação deserviços quepresta o crioulo liberto Antônio M artins da Rocha ao D outor Joaquim Augusto do Livramento na forma queabaixo sedeclara", Livro 31 do $2^{\circ}$ O fício de N otas da Cidade do D esterro (1868-69) (escrivão Leonardo J orge de Campos), fls.88. (nota datada de 31/05/1869).

${ }^{69} \mathrm{Q}$ ueeleseja- para criar um neologismo anacrônico - uma espéciede "micro-empresário ao ganho" apenastorna pergunta maisinteressante, namedida em querevelaa ambigüidadeda própria idéia de "empreendedor" quese supunha estar ao alcance de qual quer trabalhador "livre".

${ }^{70} \mathrm{~A}$ aceitação deum compromisso financeiro tão oneroso quanto aqueleaceito pelo liberto Antônio da Rocha (ver nota 68) só podeser entendida nesse contexto como uma escolha que coloca a estabilidade do trabalho (ede um trabal ho capaz de prover uma subsistência digna eestável) à frentedos ganhos pecuniários.

${ }^{71} \mathrm{~A}$ existência de atividades remuneradas durante a escravidão envolviam uma série de arranjos detrabalho entre os escravos e seus senhores. Essas atividades são fartamente documentadas emereceram aatenção detrabalhos de vários especialistas sobre a históriada escra- 
vidão. Ver, por exemplo, SO ARES, Luiz C arlos, O sescravos de ganho no Rio de aneiro do século XIX, Revista Brasileira deH iłória, no 16, mar./ago. 1988 (número dedicado à “Escravidão", organizado por Sílvia Lara), pp. 107-142; assim como o trabalho clássico deSidney CH ALH O U B, Visões da liberdade(cit.). Para o Sul do Brasil, valecitar pesquisas que apontam na mesma direção: PEN A, Eduardo Spiller. 0 jogo da face $A$ astúcia escrava frenteaossenhores eà le na Curitiba Provincial. Curitiba: Aos Q uatro Ventos, 1999; M O REIRA, Paulo Roberto S. O scativoseoshomensdebem: experiênciasnegrasno espaço urbano. Porto Alegre, 1858-1888. Porto Alegre: EST Edições, 2003.

${ }^{72}$ Essa era uma preocupação queatravessava toda a discussão sobrea importação demão-deobra estrangeira e o manejo da mão-de-obra escrava e nacional, por exemplo, na lavoura cafeeira nasúltimas décadas daescravidão (cf. LAM O U N IER, D a escravidão ao trabalho livre, cit.). É importantenotar queas diferenças entreassituações rural eurbana são muito importantes eirão merecer mais atenção na continuidade destetrabalho.

${ }^{73}$ CAST EL, R. Asmetamorfoses da questão social. cit. p. 117.

${ }^{74} \mathrm{Cf}$. LEVI, Giovanni. A herança imaterial. Trajetória de um exorcista no Piemonte do século XVII. Rio deJaneiro: Civilização Brasileira, 2000, p. 104.

${ }^{75}$ Cf. PO LAN YI, K. A grandetransformação, cit. p. 191.

${ }^{76} \mathrm{C}$ omo sugereBernard Lepetit como alternativa ao termo "filiação social" usado por Robert C astel (cf. LEPETIT, B. “Letravail del'histoire”, AnnalesH SS, mai-juin 1996, no 3, p. 537).

${ }^{77} \mathrm{C}$ f. a Introdução deAlém da escravidão, cit. p. 60.

${ }^{78} \mathrm{C}$ omo aponta $\mathrm{D}$ avid Brion $\mathrm{D}$ avis, tratava-se também de uma transformação radical na consciência moral ocidental, marcada pelo aparecimento deuma opinião relativamentegeneralizada de que a escravidão no $\mathrm{N}$ ovo $\mathrm{M}$ undo "simbolizava todas as forças queameaçavam o verdadeiro destino do homem", Cf. D AVIS, D. B. The problem of Slavery in the Age of Revolution 1770-1823. N ew York/O xford: 0 xford U niversity Press, 1999, p. 41.

${ }^{79} \mathrm{Ver}$, sobreisso, mais uma vez, a discussão sobrea idéia de cidadania, direitos eliberdadeno contexto das sociedades escravistas eno pós-emancipação, queatravessa o trabal ho deC ooper, H olt eScott, em Além da escravidão (cit.).

${ }^{80} \mathrm{Cf}$. CH ALH O U B, S. A enxadae o guarda-chuva: a luta pela libertação dos escravos ea formação da classetrabalhadora no Brasil (trabal ho apresentado no XXI Simpósio N acional da AN PU H, N iterói, junho de 2001, mimeo.).

${ }^{81} \mathrm{D}$ o ponto de vista das elites, como mostra C astel, "quando se recusa a opção literalmente reacionária de reconstituir, enquanto tais, as antigas sujeições, énecessário reconstruir, num universo ondeem princípio reina o contrato, novas regulações que sejam compatíveiscom a liberdadeemantendo as relações de dependência, sem as quaisuma ordem social éimpossível" (Cf. CAST EL, R. Asmetamorfosesda questão social, cit. p. 307).

${ }^{82}$ Cf. CAST EL, R. op. cit. p. 278. Ver, para as Américas (sobretudo o C aribe), ver H O LT, Thomas, "A essência do contrato", cit. In: Além da escravidão; SC OTT, RebeccaC. Fronteiras móveis, 'linhas decor' edivisões partidárias, In: Além da escravidão, cit. pp. 131-200; CRATO N, 
M ichael. Rembaralhando ascartas: atransição da escravidão para outras formas detrabalho no Caribebritânico (c. 1790-1890), EstudosAfro-Asáticos n. 28, 1995, pp. 31-83.

${ }^{83}$ Para usar a fel iz expressão empregada nas análises deSidney C hal houb (ver, por exemplo, "Para queservem osnarizes? Paternalismo, darwinismo social eciência racial em M achado de Assis", In: CH ALH O U B, S. et alli (org.) Arteseofíciosdecurar no Brasil. Capítulosdehistória social. Campinas: Ed. U nicamp, 2003, p. 31).

${ }^{84} \mathrm{~N}$ o Livro 58 do $2^{\circ} 0$ fício deN otasda Cidadedo D eterro (1884) (escrivão Leonardo J orgede C ampos) estão registrados uma alforria edoiscontratos de locação de serviços quetêm como contratante "C arl H oepke\& Companhia". No Livro 60 do $2^{\circ} 0$ fício deN otas da Cidadedo D esterro (1884) (escrivão L eonardo J orge de C ampos), há um contrato de locação entre Wendhausen eo crioulo liberto I dalino quese comprometia, como pagamento dos duzentos mil réis que lhe havia emprestado, trabalhar por quatro anos "com todo respeito, amor e carinho" (fls. 34).

\section{Resumo}

0 artigo aborda as ambigüidades que envolvem a noção de "liberdade de trabaIho" no século XIX, partindo de uma discussão comparativa não apenas sobre a história e a historiografia da escravidão, mas abrangendo a história social, econômica e institucional do trabalho de um modo geral. Partese do princípio de que uma abordagem deste tipo permite formular de modo mais agudo uma interpretação sobre a experiência coletiva dos trabalhadores livres e escravos, evitando algumas das armadilhas do modelo de "transição" utilizado - muitas vezes acriticamente - pela historiografia no Brasil e nas Américas para explicar a relação entre sujeição e liberdade na effera do trabal ho. Algumas das questões levantadas na primeira parte do trabalho são articuladas na discussão de uma amostra de "contratos de locação de serviços" envolvendo ex-escravos e patrões, regi strados nos cartórios de notas da cidade do D eterro entre as décadas de 40 e 80 do século XIX.

Palavras chave: escravidão, liberdade, trabalho, contratos de trabalho.

\section{Abstract}

This article examines the ambiguities raised by the concept of "labor freedom" in the XIXth century, through a comparative perspective of not only the history and historiography of savery, but also the social, economic, and institutional history of labor. It considers that this approach will allow a better understanding of the collective experience of free laborers as well as slaves, in order to criticize the "transition" model that is still used - often without any criticism - by the 
historiography on savery and free labor in Brazil and in the Americas to explain the relationship between freedom and bondage in labor history. Some of the questions raised in the first part of the article will be used to analyze a sample of labor contracts between formal slaves and their formal masters or new bosses, notarized in the city of D esterro, in Southern Brazil, between the 1840s and the 1880s. Keywords: slavery, freedom, labor, wage contracts.

(recebido em janeiro de 2005 e aprovado em junho do mesmo ano) 